\title{
Renal and Hepatic Extraction of Carboxyl-terminal Immunoreactive Parathyrin in Normal Man
}

\author{
By N. Fogh-Andersen \\ Department of Clinical Chemistry, Herlev Hospital, Herlev, Denmark,
}

\section{J. Ladefoged}

Department of Nephrology, Rigshospitalet, Copenhagen, Denmark and

\section{J. Moller-Petersen}

Department of Clinical Chemistry, Aalborg Hospital, Aalborg, Denmark

(Received January 25/March 26, 1984)

\begin{abstract}
Summary: We measured the carboxyl-terminal immunoreactive parathyrin (parathyroid hormone) in samples from twenty catheterized patients with hypertension. The radioimmunoassay reacted equally well with intact parathyrin and carboxyl-terminal parathyrin fragments. The renal arterio-venous extraction ratio (extraction ratio $=$ arterio-venous concentration difference divided by the arterial concentration) of endogenous carboxyl-terminal immunoreactive parathyrin equalled that of inulin, with mean values for both of 0.17 . The carboxyl-terminal parathyrin fragments have about the same molecular weight as inulin, and they are extracted exclusively by glomerular filtration, whereas intact parathyrin is extracted by both peritubular uptake and glomerular filtration. The findings therefore agree with a high proportion of circulating carboxyl-terminal parathyrin fragments in normal man. The mean extraction ratio of endogenous carboxyl-terminal immunoreactive parathyrin across nine livers was 0.16 . Some of the hepatic extraction might be due to cleavage and uptake of intact parathyrin, which constitutes about $15 \%$ of the circulating immunoreactive parathyrin, but the findings suggest that the liver also extracts and metabolizes the circulating carboxyl-terminal parathyrin fragments in normal man.
\end{abstract}

\section{Renale und hepatische Extraktion von carboxyterminalem immunreaktiven Parathyrin bei Gesunden}

Zusammenfassung: Carboxyterminales immunreaktives Parathyrin wurde in Proben von zwanzig katheterisierten Patienten mit Hypertonie gemessen. Der Radioimmunassay reagierte gleichgut mit intaktem Parathyrin und seinen carboxyterminalen Fragmenten. Die renale Extraktion (arteriovenöse Konzentrationsdifferenz, dividiert durch arterielle Konzentration) von endogenem carboxyterminalen immunreaktiven Parathyrin glich der von Inulin mit Mittelwerten für beide von 0,17. Die carboxyterminalen Fragmente von Parathyrin haben: etwa dieselbe relative/Molekülmasse wie Inulin, und sie werden ausschließlich durch glomeruläre Filtration extrahiert, während intaktes Parathyrin sowohl durch peributuläre Aufnahme als auch durch glomeruläre Filtration extrahiert wird. Die Ergebnisse stimmen deshalb mit einem hohen Anteil von zirkulierenden carboxyterminalen Parathyrinfragmenten bei Gesunden überein. Der mittlere Extraktionswert für endogenes carboxyterminales immunreaktives Parathyrin durch neun Lebern betrug 0,16 . Ein Teil davon könnte durch Spaltung und Aufnahme von intaktem Parathyrin bedingt sein, das etwa $15 \%$ des zirkulierenden immunreaktiven Parathyrins beträgt. Die Ergebnisse deuten aber auch darauf hin, daß die Leber beim Gesunden ebenfalls zirkulierende carboxyterminale Parathyrinfragmente extrahiert und verstoffwechselt. 


\section{Introduction}

Parathyrin (parathyroid hormone) is synthesized in the chief cells of the parathyroid glands, as part of a larger polypeptide with 115 amino acids. A 25 amino acid sequence is removed from the amino-terminal end as the molecule enters the rough endoplasmatic reticulum, and a further cleavage with removal of six amino-terminal amino acids occurs in the $\mathrm{Gol}$ gi complex, resulting in the formation of the intact hormone with 84 amino acids (1). The secreted hormone is probably cleaved by the reticuloendothelial system (the Kupffer cells) of the liver into two polypeptides, a biologically inactive carboxyl-terminal fragment, and an amino-terminal fragment with all the biological activity of the intact hormone (2-6). Some fragments may also be secreted by the parathyroid glands (7), but the importance of this source is uncertain in normal man. The carboxyl-terminal fragments have higher plasma concentrations than the amino-region of the molecule, and assays which determine carboxyl-terminal immunoreactive parathyrin in serum are both specific and sensitive for the diagnosis of parathyroid disease $(1,8-11)$. We wanted to investigate the renal and hepatic extraction of the endogenous carboxyl-terminal immunoreactive parathyrin from the circulation in normal subjects.

\section{Patients and Methods}

We examined twenty patients with hypertension of suspected renovascular origin, who had a diagnostic renal vein catheterization. Nine men and eleven women with a mean age of 49 years gave their informed consent and allowed us to take some extra blood samples from the kidneys and the liver. We obtained samples from the hepatic vein in nine patients. None of the patients received drugs known to alter calcium metabolism. Eleven of the patients had a renal artery stenosis and two had a unilateral contracted kidney, but otherwise the only diagnosis was essential hypertension.

Inulin was infused for at least $30 \mathrm{~min}$ into an arm vein, before the catheterization was made via the femoral vein. The patient was lying on an X-ray bed, and the placing of the catheter was monitored by small injections of Urografin ${ }^{\circledR}, 60 \%{ }^{1}$ ). The blood was simultaneously withdrawn from a peripheral artery and the vein of each organ. Inulin was determined according to Bojesen (12), and creatinine was determined by the picrate method using continuous flow analysis.

The carboxyl-terminal immunoreactive parathyrin was measured by radioimmunoassay with a rabbit anti-bovine-parathyrin antiserum specific for the carboxyl-terminal region of parathyrin (Institut National des Radioéléments, Fleurus, Belgium). ${ }^{125}$ I labelled intact bovine parathyrin was used as tracer, and intact bovine parathyrin as standard. The assay was calibrated with International

') Urografin is a mixture of sodium diatrizoate and methylglucamine diatrizoate.
Reference Preparation 71/324 which contains $1 \mu \mathrm{g}$ or 2 IU intact bovine parathyrin per ampoule. The carboxyl-terminal immunoreactive parathyrin consists of both intact parathyrin and carboxyl-terminal parathyrin fragments, and cross-reactivity studies indicate that the antiserum reacts equally well with both forms of parathyrin.

The extraction ratio was the arterio-venous concentration difference divided by the arterial concentration. We calculated a hypothetical half-life in a normal person as $\ln 2 / k$, with a rate constant $k$ based on the observed extraction ratios, normal rates of plasma flow, and a one-compartment extracellular volume of distribution of $14 \mathrm{l}$. We compaired paired data by the paired $t$-test.

\section{Results}

The plasma concentrations of carboxyl-terminal immunoreactive parathyrin in the artery and vein of each organ are shown in figure 1 . The mean renal extraction ratio of carboxyl-terminal immunoreactive parathyrin was 0.172 with a SEM of 0.018 . The mean hepatic extraction ratio of carboxyl-terminal immunoreactive parathyrin was 0.161 with a SEM of 0.067 .

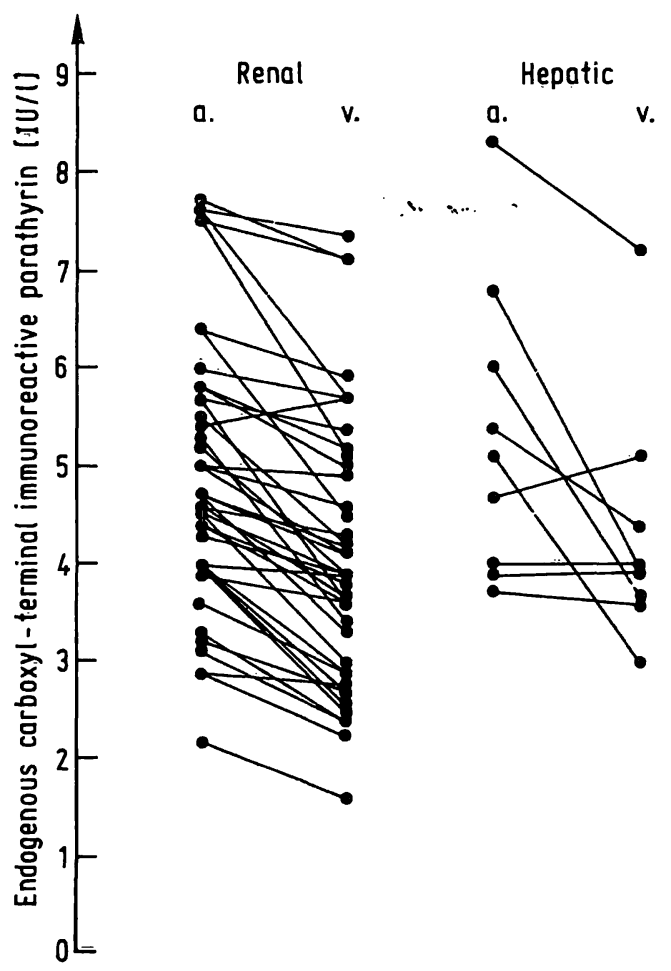

Fig. 1. The plasma concentrations of endogenoús carboxyl-terminal immunoreactive parathyrin from the artery and vein of forty kidneys and nine livers. The mean plasima concentration of carboxyl=terminal immunoreactive parathyrin in the renal artery and vein was 4.95 and $4.09 \mathrm{IU} /$, respectively ( $p<0.001$ by paired $t$-test), and in the hepatic artery and vein it was 5.32 and 4.32 IU $/$; respectively $(p<$ 0.02 by paired $t$-test). 
The mean renal extraction ratio of inulin was 0.173 with a SEM of 0.013 . The renal extraction ratio of carboxyl-terminal immunoreactive parathyrin and that of inulin did not differ, and they were positively correlated $(r=0.41, p<0.01)$. The patients had a mean clearance of creatinine of $72 \mathrm{ml} / \mathrm{min}$ (range 39 to $111 \mathrm{ml} / \mathrm{min}$ ).

Bovine and human parathyrin showed complete cross-reactivity, and the N.I.B.S.C. Research Standard for human parathyrin for immunoassay gave the assigned value (13). Our reference interval for carboxyl-terminal immunoreactive parathyrin is 2.4 to $6.4 \mathrm{IU} / \mathrm{l}$. The within-assay imprecision (SD) in normal samples was $0.30 \mathrm{IU} / \mathrm{l}(\mathrm{CV}=6 \%)$. In a comparison between our assay and that of Medi-Lab $\mathrm{A} / \mathrm{S}$, Copenhagen (laboratory no. 15 in l.c. (13)), 39 out of 46 patients' samples were concordantly categorized as normal $(n=14)$ or above normal $(n=$ 25 ), and $r=0.92$. Three patients with iatrogenic and one with idiopathic hypoparathyroidism had values below $2.0 \mathrm{IU} / \mathrm{l}$.

\section{Discussion}

Studies on animals have indicated that the kidneys extract parathyrin and amino-terminal parathyrin fragments by glomerular filtration and peritubular uptake, whereas the carboxyl-terminal parathyrin fragments are extracted by glomerular filtration only $(5,14-16)$. These experimental results have been confirmed by catheterization of hyperparathyroid patients. Corvilain et al. (17) observed a higher renal extraction ratio of endogenous amino-terminal immunoreactive parathyrin $(0.44)$ than of carboxylterminal immunoreactive parathyrin $(0.09)$ in hyperparathyroid patients, and Oldham et al. (18) found an intermediate value (0.34) with an amino-terminal antiserum against predominantly intact parathyrin. We observed a mean renal extraction ratio of carboxyl-terminal immunoreạctive parathyrin of 0.17 in normal man, which was identical to that of inulin.

Dambacher et al. (19) found that only about $15 \%$ of the circulating immunoreactive parathyrin in normals was intact parathyrin, and the rest was carboxyl-terminal parathyrin fragments. In patients with chronic renal insufficiency they found that only about $2 \%$ of the circulating immunoreactive parathyrin was intact parathyrin. Some of our subjects had a slightly reduced renal function, which may have caused a moderate increase in the concentration of circulating carboxyl-terminal parathyrin fragments. The carboxyl-terminal parathyrin fragments have about the same molecular weight as inulin, and both substances are freely filtered and eliminated exclusively by glomerular filtration in the kidneys. The findings are therefore in accord with a large proportion of circulating carboxyl-terminal parathyrin fragments in normal man.

The observed renal extraction ratio of carboxyl-terminal immunoreactive parathyrin and inulin agrees with a large proportion of carboxyl-terminal parathyrin fragments, but the substance ratio between intact parathyrin and its fragments was not determined. The antiserum we used was specific for the carboxyl-terminal region of parathyrin, and it reacted equally well with intact parathyrin and the carboxyl-terminal parathyrin fragments. Animal studies have suggested that the carboxyl-terminal parathyrin fragments are not eliminated in the liver, and that the intact parathyrin molecule is cleaved with the subsequent release of a carboxyl-terminal parathyrin cleavage product into the hepatic venous circulation (3). However, the experimental model uses injection or infusion of bovine parathyrin into dogs, and the results do not necessarily apply to normal man. With only a small fraction of the circulating immunoreactive parathyrin being intact parathyrin, cleavage alone could not explain the observed hepatic extraction of carboxyl-terminal immunoreactive parathyrin. We therefore suggest that the liver in addition extracts and metabolizes the circulating carboxylterminal parathyrin fragments.

The liver receives most of its blood supply from the portal vein, but we used blood from the hepatic artery and vein. The lower concentration in the hepatic vein might therefore be due to mixing with portal venous blood, if the concentration of carboxyl-terminal immunoreactive parathyrin was lower in the portal vein. However, Moosa et al. (20) did not find a lower concentration of carboxyl-terminal immunoreactive parathyrin in the portal vein than in the external jugular vein in patients undergoing abdominal surgery. The low overall clearance of carboxyl-terminal immunoreactive parathyrin in uraemia does not exclude a hepatic extraction of the carboxyl-terminal parathyrin fragments in normals, because the renal insufficiency itself may impair the hepatic metabolism $(14,21)$.

We were confined to the investigation of patients with hypertension, because the present study alone did not justify the risk of a catheterization in healthy individuals. The calculated hypothetical half-life of carboxyl-terminal immunorective parathyrin in a normal person was $40 \mathrm{~min}$. This agrees with the value obtained in hyperparathyroid patients after subtotal parathyroidectomy (22). 


\section{References}

1. Habener, J. F. (1981) Clin. Biochem. 14, 223-229.

2. Canterbury, J. M., Bricker, L. A., Levey, G. S., Kozlovskis, P. L., Ruiz, E., Zull, J. E. \& Reiss, E. (1975) J. Clin. Invest. $55,1245-1253$.

3. Martin, K., Hruska, K., Greenwalt, A., Klahr, S. \& Slatopolsky, E. (1976) J. Clin. Invest. 58, 781-788.

4. D'Amour, P., Segre, G. V., Roth, S. I. \& Potts, J. T. (1979) J. Clin. Invest. 63, 89-98.

5. Martin, K. J., Hruska, K. A., Freitag, J. J., Klahr, S. \& Slatopolsky, E. (1979) N. Engl. J. Med. 301, 1092-1098.

6. Segre, J. V., Perkins, A. S., Witters, L. A. \& Potts, J. T. (1981) J. Clin. Invest. 67, 449-457.

7. Flueck, J. A., Di Bella, F. P., Edis, A. J., Kehrwald, J. M. \& Arnaud, C. D. (1977) J. Clin. Invest. 60, 1367-1375.

8. Arnaud, C. D., Goldsmith, R. S., Bordier, P. J. \& Sizemore, G. W. (1974) Am. J. Med. 56, 785-793.

9. Voll, R., Schmidt-Gayk, H. \& Wiedemann, J. (1978) J. Clin. Chem. Clin. Biochem. 16, 269-277.

10. Gautvik, K. M., Teig, V., Halvorsen, J. F., Arnesen, E., Myhre, L. Heimann, P. \& Tallman, R. (1979) Scand. J. Clin. Lab. Invest. 39, 469-478.

11. Boyd, J. C., Lewis, J. W., Slatopolsky, E. \& Ladenson, J. H. (1981) Clin. Chem. 27, 574-579.

12. Bojesen, E. (1952) Acta Med. Scand. Suppl. 266, 275-282.
13. Zanelli, J. M. \& Das, R. E. G. (1980) J. Endocrinol. 86, 291-304.

14. Hruska, K. A., Kopelman, R., Rutherford, W. E., Klahr, S. \& Slatopolsky, E. (1975) J. Clin. Invest. 56, 39-48.

15. Singer, F. R., Segre, G. V., Habenęr, J. F. \& Potts, J. T. (1975) Metabolism 24, 139-144.

16. Martin, K. J., Hruska, K. A., Lewis, J., Anderson, C. \& Slatopolsky, E. (1977) J. Clin. Invest. 60, 808-814.

17. Corvilain, J., Manderlier, T., Struyven, J., Fuss, M., Bergans, A. Nijs, N. \& Brauman, H. (1977) Horm. Metạb. Res. 9, $239-242$.

18. Oldham, S. B., Finck, E. J. \& Singer, F. R. (1978) Metabolism 27, 993-1001.

19. Dambacher, M. A., Fischer, J. A., Hunziker, W. H., Born, W., Moran, J., Roth, H. R., Delvin, E. E. \& Glorieux, F. H. (1979) Clin. Sci. 57, 435-443.

20. Moosa, A. R., Hall, T. J., Hughes, R. G., Wood, R. A. B., Mackie, C. R. \& Hall, A. W. (1978) J. Surg. Res. 25, 445-448.

21. Hruska, K. A., Korkor, A., Martin, K. \& Slatopolsky, E. (1981) J. Clin. Invest. 67, 885-892.

22. Freitag, J., Martin, K. J., Hruska, K. A., Anderson, C., Conrades, M., Ladenson, J. H., Klahr, S. \& Slatopolsky, E. (1978) N. Engl. J. Med. 298, 29-32.
Dr. N. Fogh-Andersen

Department of Clinical Chemistry

Herlev Hospital

DK-2730 Herlev 